\title{
ISOLATION, CHARACTERIZATION AND IMMOBILIZATION OFGLUCOSE OXIDASE FROM ASPERGILLUS NIGER 1- ISOLATION AND PURIFICATION
}

\author{
Abdul-Aziz A. Abbas Waleed A. Mahmood
}

Food Sci. and Biotech. Dept., College of Agric. and Forestry, Mosul Univ., Iraq

\begin{abstract}
Two strains of Aspergillus niger were propagated on Czapek broth medium using submerged culture in a shaker incubator at $30{ }^{\circ} \mathrm{C}$ and $125 \mathrm{rpm}$ to produce glucose oxidase. The strain ATCC 166808 was selected because it gave higer enzymatic activity than the strain IMI 84305. The presence of glucose and sucrose in the medium at concentration of $20 \mathrm{gm} / 1$ for each enhanced maximum enzyme production after 3 days of incubation. The enzyme was found to be intracellular and the sonication time required to rupture the cellular walls was 15 minutes at $10 \mathrm{KHz}$. The enzyme was precipitated from the cell-free extract by the addition of 2 volumes of cold acetone and was partially purified by gel filtration chromatography using Sephadex G-150 followed by ion-exchange chromatography in a DEAE-cellulose column. A specific activity of 8528.6 units $/ \mathrm{mg}$ protein and a purification of 53.2 folds with a yield of $47.6 \%$ was achieved.
\end{abstract}

\section{INTRODUCTION}

Glucose oxidase ( $\beta$-D-glucose: oxygen oxidoreductase, E.C. 1.1.3.4) was discovered in 1928 by Muller in molds of the genera Aspergillus and Penicellium. After that, the enzyme was isolated from other fungi. This enzyme has a high specificity toward $\beta$-D-glucose which is oxidized -in the presence of molecular oxygen- into gluconic acid and hydrogen peroxide (Hayashi and Nakamura, 1976 and Rothberg et al., 1999). Glucose oxidase has a significant economical importance. It is used for the production of gluconic acid, for the removal of glucose and / or oxygen from some food products such as dried eggs, fruits, juices, meat and milk products in order to prevent oxidation and / or browing. It is also used - in conjugation with peroxidase - for specific determination of glucose and in biosensors manufacturing (El-Enshasy et al., 2001).

A.niger is considered to be the main producer of commercial glucose oxidase and many other enzymes, organic acids, growth regulators and other compounds which are generally recognized as safe (GRAS). Several carbon sources were used to propagate this mold such as hydrolyzed corn starch (Kona et al., 2001), glucose, sucrose, and molasses (Hatzinikolaou and Macris, 1995) and many other hexoses and pentoses (El-Enshasy et al., 2001). Many workers had studied the various methods of extraction and purification of the enzyme from cell-free extract (Fiedurek and Gromoda, 1996; Kalisz et al., 1997; Torres et al., 1998; Kim et al., 2001; Kona et al., 2001). The aim of the present work was to study some conditions required for the production of 
glucose oxidase from the mold $A$. niger propagated on a submerged culture followed by isolation and partial purification of the enzyme.

Part of MSc. Thesis of the first auther

Received 2/8/2006 Accepted 30/11/2006 


\section{MATERIALS AND METHODS}

Microorganisms: Two Aspergillus niger strains (ATCC 166808 and IMI 84305) were obtained from Food Sci. and Biotechnology Dept., College of Agriculture and Forestry, Mosul University.

Growth conditions: Cultures were propagated on potato dextrose agar slants at $30{ }^{\circ} \mathrm{C}$ for 7 days. Spore suspension was obtained by adding $5 \mathrm{ml}$ of sterile distilled water to the slant surface and the spores were removed with a loop. The spore suspension was transferred to a sterile test tube and $1 \%$ of tween 80 was added. Spore count was determined using a hemocytometer. An inoculum size containing about $1.5 \times 10^{6}$ spores was transferred to $500 \mathrm{ml}$ Erlenmeyer flasks containing $150 \mathrm{ml}$ of sterile Czapek broth medium. The flasks were incubated at $30 \mathrm{C}^{\circ}$ in a shaker incubator operating at $125 \mathrm{rpm}$. The enzyme activity in the cell-free extract was assayed everyday throughout the incubation period.

To study the effect of the type and concentration of carbon sources on the enzyme production, glucose and sucrose were added to the growth medium at concentrations of $(10+10),(20+20),(30+30)$, and $(40+40) \mathrm{g} / \mathrm{l}$. Also each sugar was used separately using the above concentrations.

Isolation and purification of the enzyme: At the end of the incubation period, the mold biomass was harvested by filtration through Whatmann No. 1 filter paper, washed by potassium phosphate buffer $(0.1 \mathrm{M}, \mathrm{pH} 6)$ and suspended in the same buffer ( $75 \mathrm{~g}$ biomass $+25 \mathrm{ml}$ buffer), The suspension was freezed at $15 \mathrm{C}^{\circ}$ for 24 hours and then subjected to sonication at $10 \mathrm{KHz}$ to rupture the cellular walls, Cell-free extract was obtained by centrifugation at $9000 \times \mathrm{g}$ for 10 minutes using a refrigerated centrifuge. The enzyme was then precipitated by adding cold acetone ( $1-2$ volumes) with gentle stirring for 1 hour. The mixture was centrifuged at $9000 \times \mathrm{g}$ for 20 minutes and the precipitate was suspended in a small amount of phosphate buffer and applied on the top of a column $(1.6 \times 65 \mathrm{~cm})$ of Sephadex G-150 that had been equilibrated with phosphate buffer $(0.05 \mathrm{M}, \mathrm{pH} 6)$. The column was then eluted with the same buffer at a flow rate of $12 \mathrm{ml} /$ hour. Enzyme contained fractions of $2 \mathrm{ml}$ each were pooled and applied to the top of a column $(1.6 \times 25 \mathrm{~cm})$ of DEAEcellulose equilibrated with the same buffer. The column was washed with a linear $\mathrm{NaCl}$ gradient of $0-0.7 \mathrm{M}$ in phosphate buffer at a flow rate of $24 \mathrm{ml} /$ hour. Active fractions of $3 \mathrm{ml}$ each were pooled.

Assay of glucose oxidase activity: The enzymatic activity was measured by the method described by Bergmeyer et al.(1970) by measuring the increase of absorbance at $436 \mathrm{~nm}$ due to the oxidation of guaiacol in the reaction mixture containing peroxidase. Enzyme unit is defined as the amount of the enzyme which liberate one micromole of hydrogen peroxide per minute under the experiment conditions.

Protein determination: Protein content was estimated according to the method of Lowry et al. (1951) using bovine serum albumin as the standard. 
Choice of mold strain: The two A. niger strains (ATCC 166808 and IMI 84305)were tested for glucose oxidase productability through their propagation on Czapek broth medium in a submerged culture at $30 \mathrm{C}^{\circ}$ and 125 rpm for 3 days. At the end of the incubation period, the enzymatic activity was assayed in the cell-free extract and in the cultural filtrate of both strains. Also the wet biomass was measured.

Table (1): Glucose oxidase activity and biomass weight in two strains of $A$. niger.

\begin{tabular}{|l|c|c|c|c|c|}
\hline Strain & $\begin{array}{c}\text { Volume } \\
\text { of cell- } \\
\text { free } \\
\text { ext.(ml) }\end{array}$ & $\begin{array}{c}\text { Enz. activity } \\
\text { in cell-free } \\
\text { ext.(unit/ml) }\end{array}$ & $\begin{array}{c}\text { Enz. } \\
\text { activity } \\
\text { (unit/l } \\
\text { medium) }\end{array}$ & $\begin{array}{c}\text { Wet } \\
\text { biomass } \\
\text { weight } \\
\text { (g/l edium) }\end{array}$ & $\begin{array}{c}\text { Enz.activity } \\
\text { in cult. } \\
\text { filtrate } \\
\text { (unit/ml) }\end{array}$ \\
\hline $\begin{array}{l}\text { A.niger } \\
\text { ATCC } \\
\text { 166808 }\end{array}$ & 110 & 119 & 13090 & 260 & 4.3 \\
\hline $\begin{array}{l}\text { A.niger } \\
\text { IMI } \\
84305\end{array}$ & 95 & 103 & 9785 & 216 & 2.4 \\
\hline
\end{tabular}

As shown in the Table (1), the enzymatic activity in the cell-free extract and the biomass weight for the strain ATCC 166808 was higher than those for the strain IMI 84305. The first strain produced 13090 enzyme units/l of the medium, while the second strain produced 9785 enzyme units/l. It was also noticed that the enzyme concentration in the cultural filtrate of both strains was low so that it was neglected. This indicates that most of the enzyme was intracellular.

Effect of incubation time on enzyme production: This was estimated by the incubation of the strain ATCC 166808 on Czapek broth for 7 days and assaying glucose oxidase activity in the cell-free extract every day.

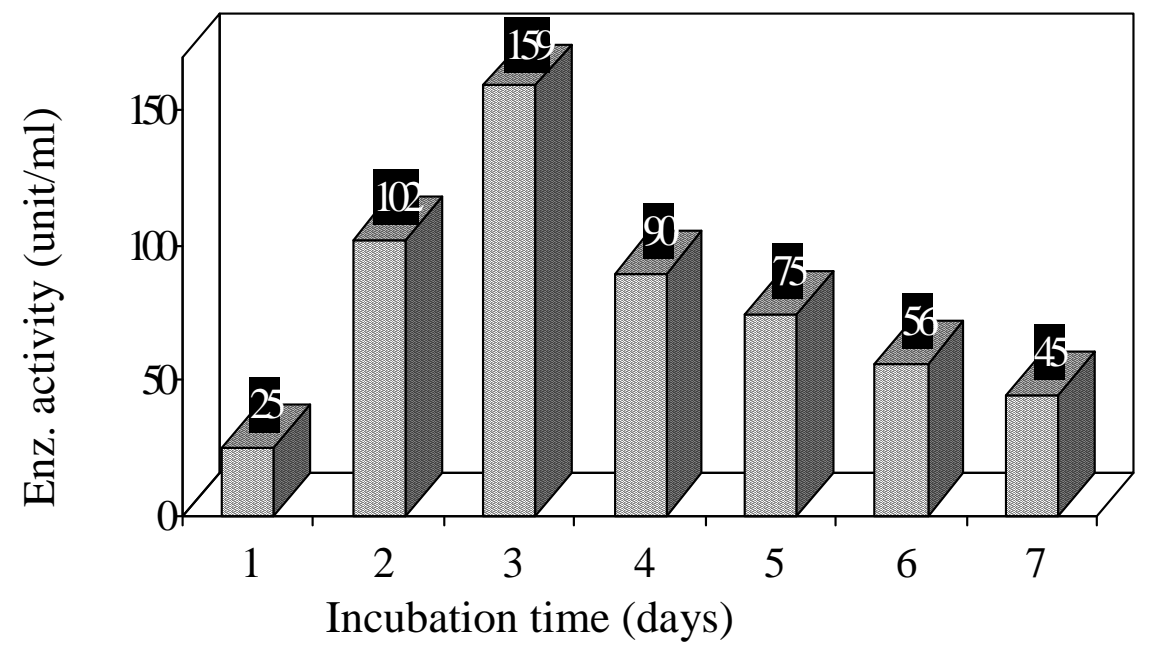

Fig. (1): Effect of incubation time on glucose oxidase production by A. niger 
Fig. (1) shows that the activity after one day was very low and began to increase significantly through the second day of incubation (102 units/ml). Maximum production of the enzyme was reached after 3 days (159 units/ml) and after that it began to decrease gradually. This decrease may be due to the raising of the medium acidity and the accumulation of some toxic metabolites that may affect the enzyme production and the stability of the produced enzyme. The lysis of cells and the leakage of the enzyme to the cultural medium could be another reason because it was noticed that the decrease in enzyme activity in the cell-free extract was accompanied by increased activity in the cultural filtrate especially through the sixth and seventh days of incubation. However, a similar result was achieved by Hellmuth et al., (1995) who used a genetically engineered $A$. niger strain and found that maximum enzyme production was obtained after 60 hours of incubation. After $100-125$ hours, the cells began to lyse gradually with increase of respiration, but they noticed that living cells utilize the components of the lysed cells and the produced gluconic acid untill 190 hours of incubation. In an other mutant strain of $A$. niger, the maximum glucose oxidase production was obtained after $3-4$ days of incubation (fiedurek and gromoda, 1996).

Effect of carbon source and concentration on enzyme production: The effect of the addition of glucose, sucrose and their mixture on $A$. niger productivity of glucose oxidase was studied. After 3 days of incubation, the enzymatic activity in the cell-free extract was measured (Fig 2).

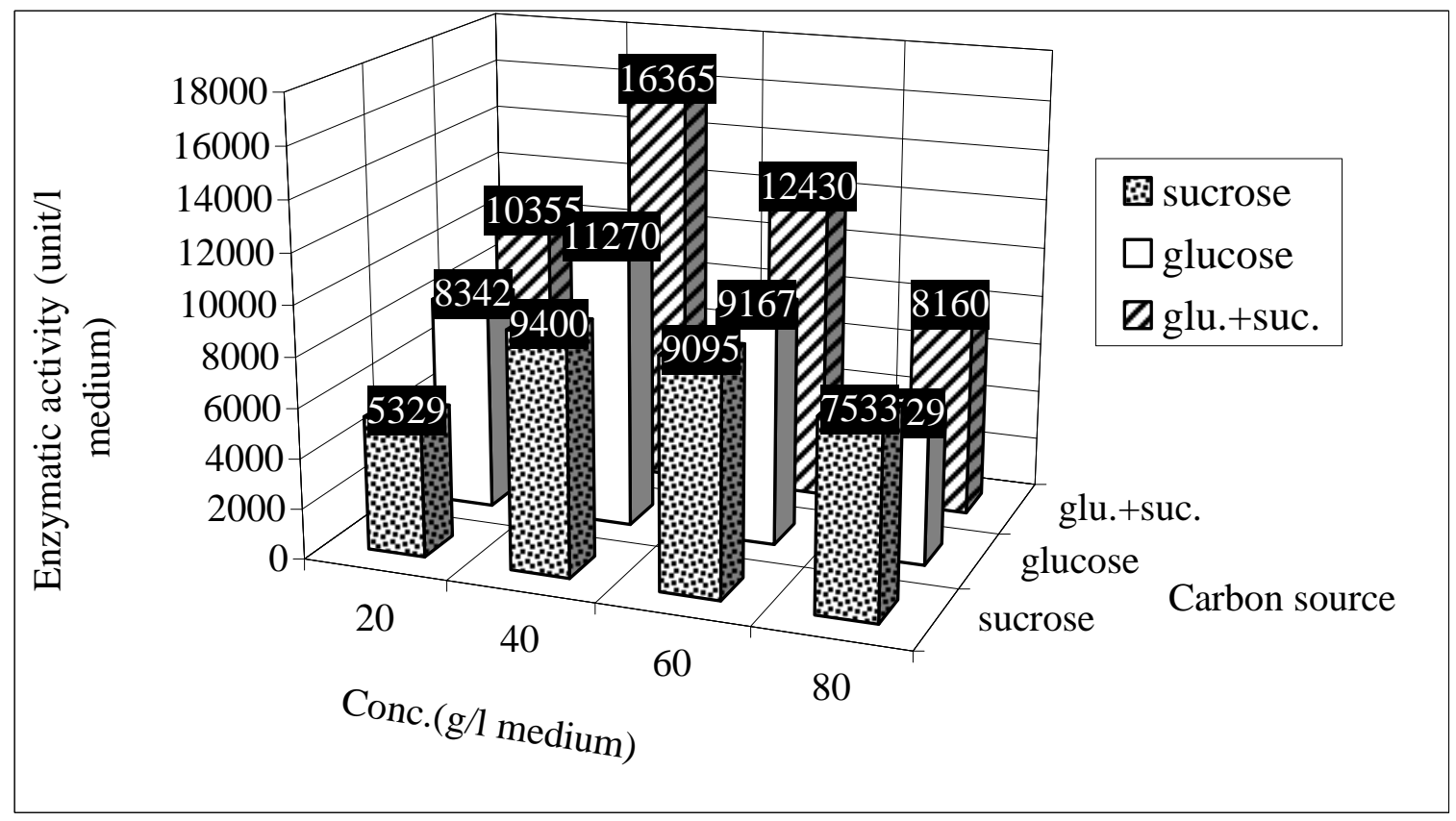

Fig. (2): Effect of carbon sources on glucose oxidase production by A. niger.

The highest enzyme production (16365 units/l) was achieved when a mixture of the two sugars was added to the propagation medium at concentration of $(20+20) \mathrm{g} / \mathrm{l}$. A lower production was obtained by the addition 
of glucose alone (11270 units/l) followed by sucrose (9400 units/l) using the same concentration $(40 \mathrm{~g} / \mathrm{l})$.

This may be explained by the fact that glucose acts as a rapid source of energy which enhances the growth of the cells at earlier stages untill the cells begin to produce their own enzymes and hydrolyze sucrose. However, the addition of glucose alone at high concentration in the early growth stages may inhibits the synthesis of the enzyme due to its catabolic repression effect on the mold cells. On the other hand, the use of sucrose as a unique carbon source may reduce growth rate especially at early growth stage due to absence of its hydrolyzing enzyme (invertase). Thus, the presence of glucose together with sucrose in the medium could be the best.

The effect of sugars concentrations on the enzyme production was also studied. The concentrations used were 20, 40, 60, and $80 \mathrm{~g} / \mathrm{l}$. The best concentration was found to be $40 \mathrm{~g} / \mathrm{l}$ for all sugars used.

Previous studies did not mention the use of carbon source mixtures for glucose oxidase production. However, Hatzinikolaou and Macris (1995) used some carbon sourses such as molasses, sucrose, fructose and starch. They found that sucrose had given the highest enzyme productivity from A. niger. Kona et al.(2001) found that maximum glucose oxidase productivity was achieved when sucrose was added in a concentration of $70 \mathrm{~g} / \mathrm{l}$, but when glucose was used, $20 \mathrm{~g} / \mathrm{l}$ was found to be the best concentration. In the case of Penicillium pinophilium, the highest productivity was obtained when sucrose was added at concentration of $40 \mathrm{~g} / \mathrm{l}$ (Rando et al., 1996).

Effect of sonication time on the efficiency of the enzyme extraction: The enzyme was extracted from cells by freezing the mold mycelium for 24 hours followed by sonication at $10 \mathrm{KHz}$.

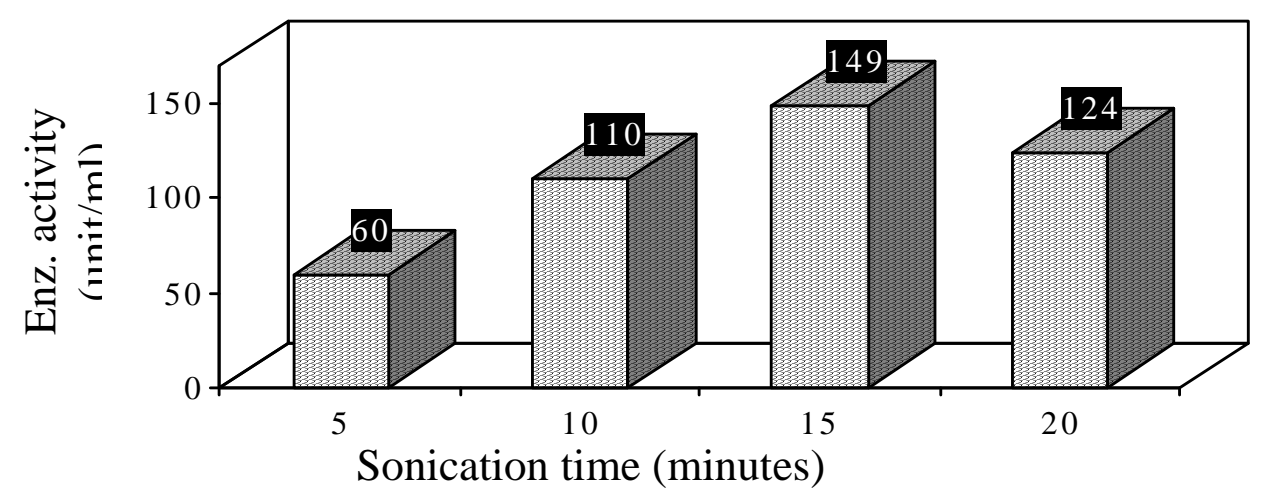

Fig. (3): Effect of sonication time on the extraction efficiency of glucose oxidase from A. niger cells

Fig (3) shows the effect of sonication time on the efficiency of rupturing the cellular walls which was expressed by assaying the enzymatic activity in the cell-free extract. 15 minutes was required to reach maximum activity. Upon exceeding this period, the activity began to decrease. This may be due to the denaturing effect of sonicator vibrations on the enzyme molecules. For this 
reason, other assistant techniques, such as freezing and blending, could be used prior to sonication to reduce its denaturing effect (Hatzinikolaou and Macris, 1995; Pluschkell et al., 1996).

Isolation and purification of glucose oxidase: The enzyme was precipitated from the cell-free extract by adding cold acetone $\left(-15 \mathrm{C}^{\circ}\right)$ with gentle stirring. Three concentrations of acetone were tested (1, 1.5, 2 volumes). The precipitate was dissolved in $10 \mathrm{ml}$ of phosphate buffer and the enzymatic activity and protein content were assayed. The enzymatic activities in the precipitate were 517, 1003 and 1479 units/ml when acetone concentrations of $1,1.5$ and 2 volumes were used. Table 2 shows that the addition of two volumes of acetone gave the highest enzymatic activity in the precipitate $(1479 \mathrm{unit} / \mathrm{ml})$ with a specific activity of 2958 unit / mg protein. The enzyme yield of this stage was $81.9 \%$.

Gel filtration and ion exchange chromatography: After acetone precipitation, the enzyme was subjected to partial purification through two steps. In the first, the enzyme solution was applied to a gel filtration column of Sephadex G-150.

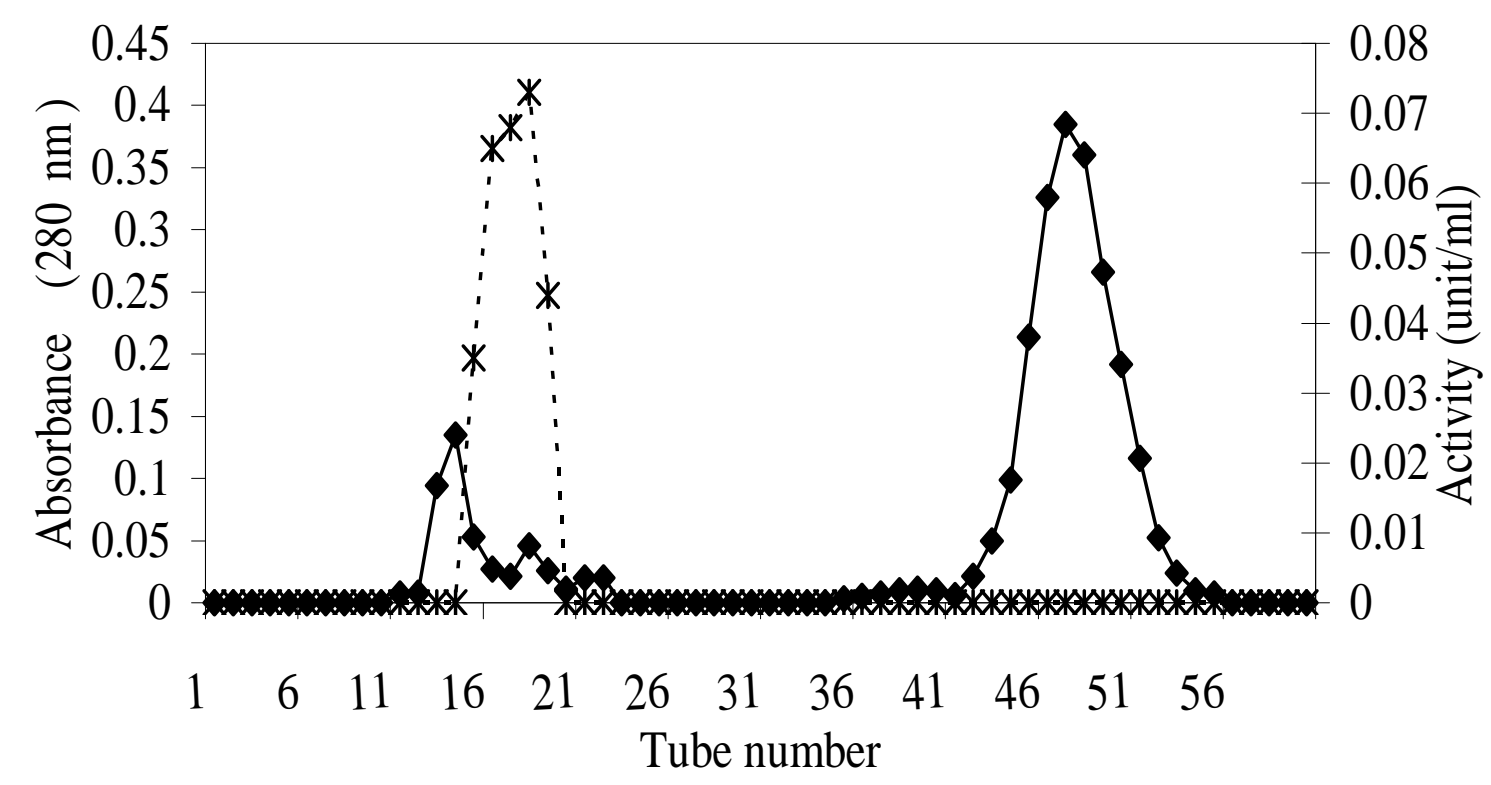

Fig. (4):Gel filtration of glucose oxidase on Sephadex G-150 with potassium phosphate buffer(0.05M,pH6).( $\bullet$ protein, $\not--\nless$ activity).

As shown in the Fig. (4), the void volume of the column was $28 \mathrm{ml}$ and the enzyme was eluted in the fractions $16-20$ (each fraction was $2 \mathrm{ml}$ ). The enzymatic activity after this step was $198.5 \mathrm{unit} / \mathrm{ml}$ and the specific activity was 8270.8 units $/ \mathrm{mg}$ protein with a yield of $55 \%$ and a purification of 51.6 folds. The second step of purification involved ion-exchange chromstography 
in which the active fractionsthat pooled from the previous step were applied to a column of DEAE-cellulose and eluted with $50 \mathrm{ml}$ phosphate buffer (column volume) followed by linear gradient elution with sodium chloride $(0-0.7 \mathrm{M})$. The enzyme was eluted at $0.4 \mathrm{M}$ of $\mathrm{NaCl}$. Active fractions $(24 \mathrm{ml})$ were pooled and the enzymatic activity and protein content were assayed. The activity was found to be 119.4 units $/ \mathrm{ml}$ and the specific activity was 8528.6 units $/ \mathrm{mg}$ protein. A purification of 53.2 folds with a yield of $47.6 \%$ was achieved (Table 2).

As shown in the Fig. (5), there is no protein peak other than that of the glucose oxidase. This may explain why the ion-exchange step did not give a significant increase in the specific activity and this might be due to that the gel filtration step was sufficient to bring the enzyme to a good degree of purification.

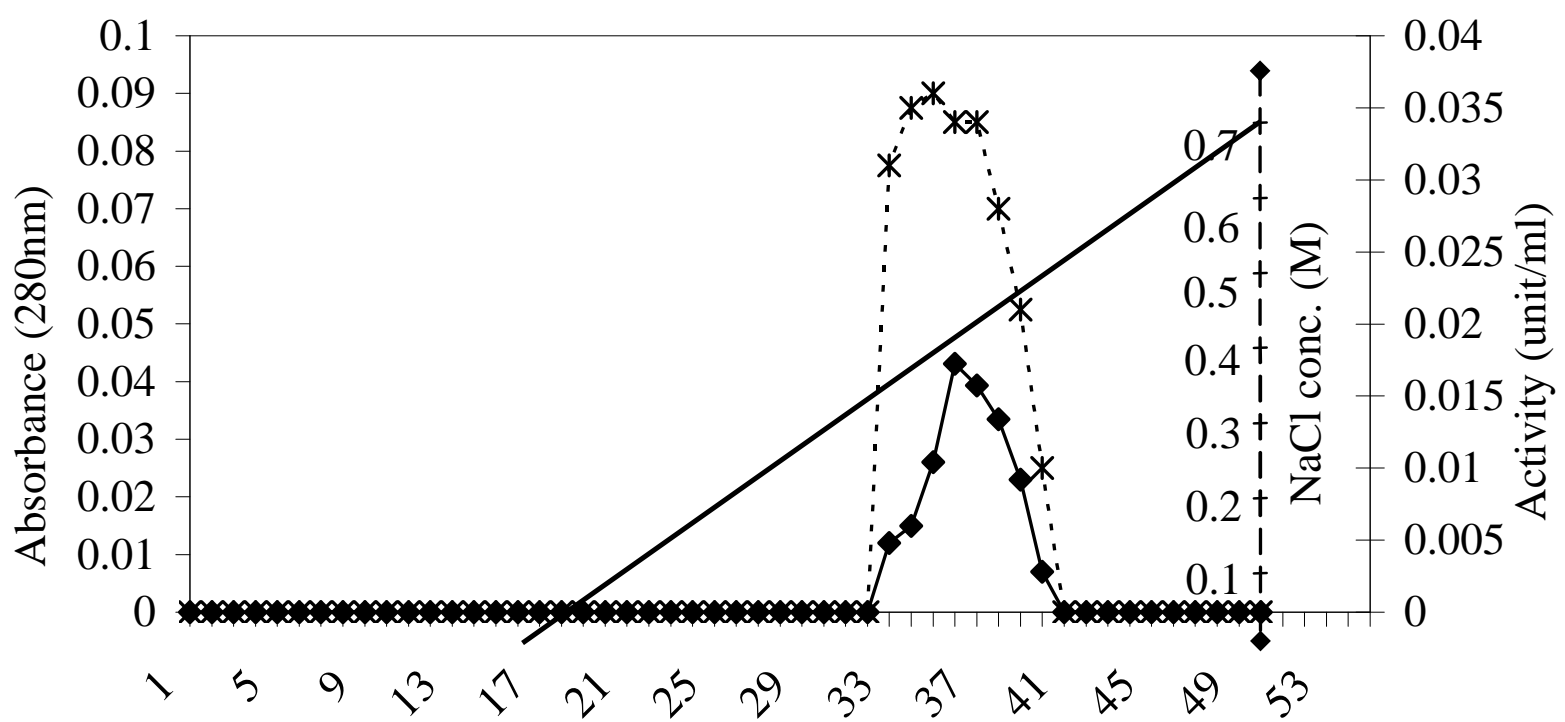

Tube No.

Fig. (5):Gradient ion-exchange of glucose oxidase on DEAE-cellulose column $(1.6 \times 25 \mathrm{c}$ with pot. phosph. buffer $(0.05 \mathrm{M}, \mathrm{pH} 6)$ containing $\mathrm{NaCl}(0-0.7 \mathrm{M})$.

Table (2): Purification steps of glucose oxidase from Asp. niger

\begin{tabular}{|l|c|c|c|c|c|c|}
\hline \multicolumn{1}{|c|}{$\begin{array}{c}\text { Purification } \\
\text { step }\end{array}$} & $\begin{array}{c}\text { Volume } \\
\text { (ml) }\end{array}$ & $\begin{array}{c}\text { Enzymic } \\
\text { activity } \\
\text { (unit/ml) }\end{array}$ & $\begin{array}{c}\text { Protein } \\
\text { conc. } \\
(\mathrm{mg} / \mathrm{ml})\end{array}$ & $\begin{array}{c}\text { Specific } \\
\text { activity } \\
\text { (unit/mg) }\end{array}$ & $\begin{array}{c}\text { Purification } \\
\text { (fold) }\end{array}$ & $\begin{array}{c}\text { Yield } \\
(\%)\end{array}$ \\
\hline Cell-free ext. & 115 & 175 & 0.98 & 160.2 & 1 & 100 \\
\hline Acetone ppt & 10 & 1479 & 0.5 & 2958 & 18.5 & 81.9 \\
\hline $\begin{array}{l}\text { Sephadex } \\
\text { G-150 }\end{array}$ & 50 & 198.5 & 0.024 & 8270.8 & 51.6 & 55 \\
\hline $\begin{array}{l}\text { DEAE- } \\
\text { cellulose }\end{array}$ & 72 & 119.4 & 0.014 & 8528.6 & 53.2 & 47.6 \\
\hline
\end{tabular}




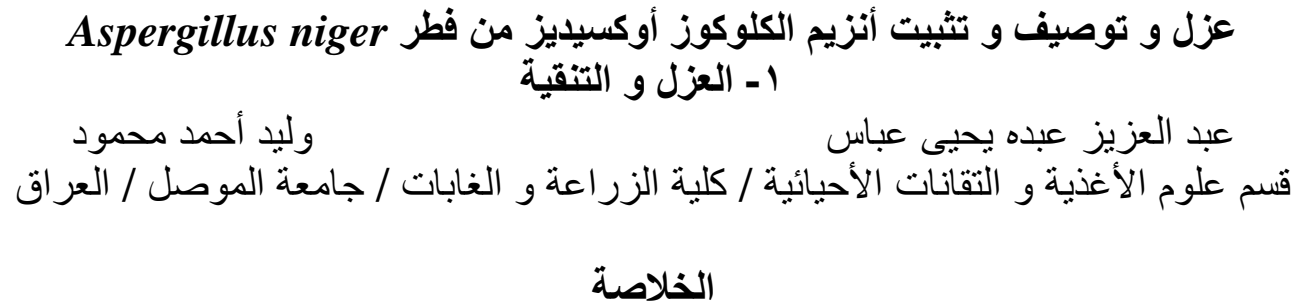

تم تتميـة سلالتين من فطر ATCC 166808 ( Aspergillus niger

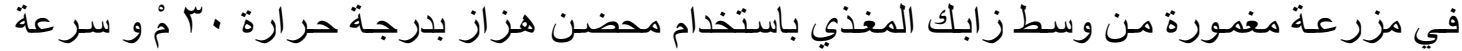

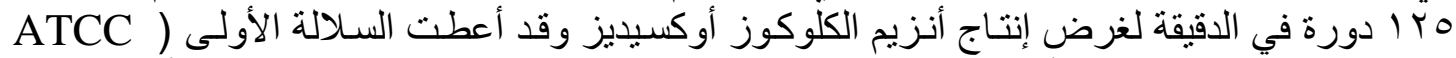

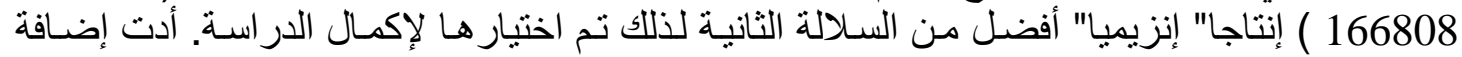

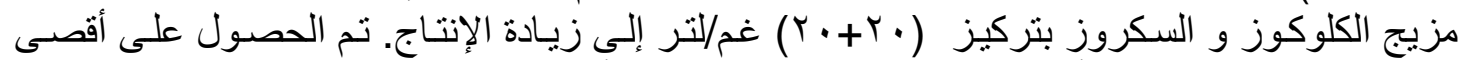

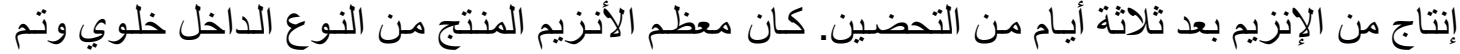

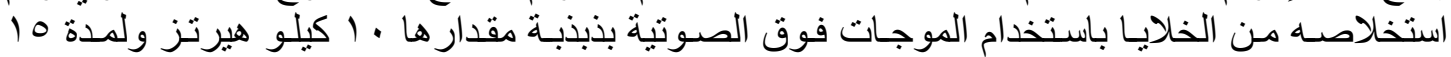

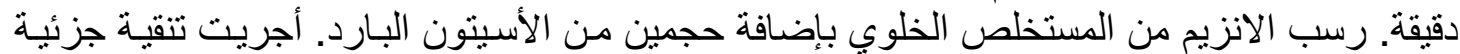

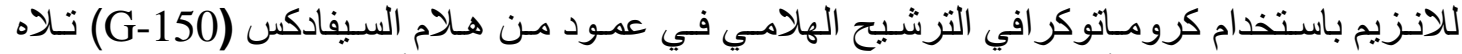

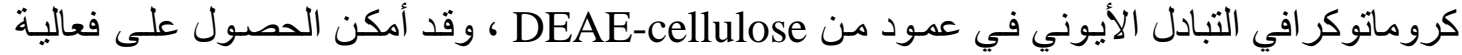

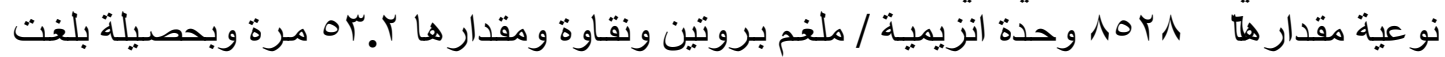
$\% \leqslant \vee .7$

\section{REFERENCES}

Bergmeyer, H.U.; J. Bergmeyer and M. Grassl (1970). Methods of Enzymatic Analysis. Weinheim, Deerfield Beach, Fla. pp:416.

El-Enshasy, H.; K. Hellmuth and U. Rinas (2001). Gpda-promoter- controlled production of glucose oxidase by recombinant Aspergillus niger using non-glucose carbon sources. Applied Biochemistry and Biotechnology, 90: 57-66.

Fiedurek, J. And A. Gromoda (1996). Selection of biochemical mutants of Aspergillus niger with enhanced catalase production. Appl. Microbiol. Biotechnol., 19: 313-316.

Hatzinikolsou, D.G. and B.J. Macris (1995). Factors regulating of glucose oxidase by Aspergillus niger. Enzyme and Microbial Technology, 17: 530-534.

Hayashi, S. and S. Nakamura (1976). Comparison of fungal glucose oxidase. Chemical, physicochemical and immunological studies. Biochimica et Biophysica Acta, 438: 37-48.

Hellmuth, K.; S. Pluschkell; J.K. Jung; E. Ruttkowski and U. Rinas (1995). Optimization of glucose oxidase production by Aspergillus niger using genetic and process engineering techniques. Appl. Microbiol. Biotechnol., 43: 978-984.

Kalisz, H.M.; J. Hendle and R.D. Schmid (1997). Structural and biochemical properties of glucosylated and deglycosylated glucose oxidase from Penicillium amagasakiense. Appl. Microbiol. Biotechnol., 47: 502-507.

Kim, M.Y.; H.J. Chung; S.Y. Hong; H.R. Kim; J.C. Lee; S.M. Park; J.H. Lee; M.S. Yang and D.H. Kim (2001). Characterization of a novel allele of glucose

oxidase from a Korian wild type strain of Aspergillus niger. Molecules and Cells, 11(3): 281-286. 
Kona, R.P.; N. Qureshi and J.S. Pai (2001). Production of glucose oxidase using Aspergillus niger and corn steep liqour. Bioresource Technology, 78: $123-126$.

Lowry,O.H.; N.H. Rosebrough; A.L. Farr and R.J. Randall (1951). Protein measurement with the folin phenol reagent. The J. of Biological chemistry, 193: 265-275.

Pluschkell, S.; K. Hellmuth and U. Rinas (1996). Kinetics of glucose oxidase excretion by recombinant Aspergillus niger. Biotechnology and

Bioengineering, 51: 215-220.

Rando, D.; G.W. Kohring and F. Giffhorn (1997). Production, Purification and characterization of glucose oxidase from a newly isolated strain of Penicillium pinophilum. Appl. Microbiol. Biotechnol., 48: 34-40.

Rothberg, A.; A. Weegar; R.V. Schalien; K. Fagervik; M. Rydstrom and K. Lind (1999). Optimization of an Aspergillus niger glucose oxidase production process. Bioprocess Engineering, 21: 307-312.

Torres, E.F.; J.C. Lopez; M.G. Rivero and M.G. Rogas (1998). Kinetics of growth of Aspergillus niger during submerged, agar surface and solid state fermentations. Process Biochemistry, 33(2): 103-107. 